\title{
Labor Education in the Caribbean: A Critical Evaluation of Barbados, Jamaica and Trinidad
}

\author{
Danny Roberts and Lauren Marsh \\ University of the West Indies, Open Campus
}

\section{Introduction}

The achievements of the labor movement in the Caribbean are generally historicized without highlighting the contribution of labor colleges to the function and survivability of trade unions. For more than fifty years, labor colleges have played a critical role in developing the knowledge and skill sets of union members who had an interest in labor studies. Many will attribute the heydays of the Caribbean labor movement in the mid-1900s to the intellectual thrust given to the trade union movement by labor colleges. During this period, trade unions relied heavily on labor colleges for intellectual support and advice primarily on matters that required in-depth academic investigation. Support from the labor colleges enhanced the reputation of the labor movement by shifting popular notions that the trade union movement consisted only of the poor and illiterate working class. The effects of these parallel training activities have been positive for both the leadership of the trade union movement and the overall impact they have had on labor-management relationships. There has been a noted change in the pattern of trade union leadership where "the first generation leaders, considered by many as demagogic and messianic, have given way increasingly to a younger and more formally educated second and third generation leadership". 1

The International Labour Organisation (ILO) played a part in the development of labor education in the Caribbean during the early 1970s when it established its Caribbean Office in Port-of-Spain, Trinidad, and began to provide substantial technical assistance to the various labor colleges in their formative years. They have also financed several training workshops, seminars, and symposia in labor education over the years. In the smaller Eastern Caribbean territories, where there are no labor colleges, financial support has largely been through the Danish International Development Agency (DANIDA) for on-the-spot education and training activities. In addition to these training activities, some of the major unions in the Caribbean have also undertaken their own training programs, and the Caribbean Congress of Labor (CCL), the confederation of trade union organizations across the Caribbean region, conducted regional workshops and seminars on labor education in those early years, with financial support from other sources.

The colleges have also provided educational/intellectual support for many union leaders who made the transition to electoral politics. Prominent 
politicians such as Baldwin Spencer, former Prime Minister of Antigua and Barbuda, and Portia Simpson Miller, Prime Minister of Jamaica, are among those who have benefitted from labor education. Many persons within civil society, especially youth groups and women movements, have also gained significantly from courses and initiatives spearheaded by labor colleges. For example, between 1991 and 1992, "in response to the need identified by female members of trade unions for an education programme specially geared to address issues of concern to female workers and to develop female union members," a Women Trade Union Membership project was implemented across the region. ${ }^{2}$ Since the beginning of the new millennium, the labor colleges have expanded their course offerings to meet the work-related/employment concerns associated with the globalization process.

This article focuses on the contribution made by labor colleges to the development of the labor movement in the Caribbean. The labor colleges discussed are the Barbados Workers' Union Labor College (BWULC), the Hugh Lawson Shearer Trade Union Education Institute (HLSTUEI) in Jamaica, and the Cipriani Labor College and Cooperative Studies in Trinidad and Tobago. The report begins with an overview of the history of labor education in the Caribbean, followed by a summary of the core courses and programs offered by each labor college, and the final section of the report provides an examination of the contribution labor colleges have made to the development of the labor movement within the Caribbean region.

\section{History of Labor Education in the Caribbean}

In 1959, a labor education conference held at the University College of the West Indies (UCWI) recognized that the industrial relations system in the Caribbean could be developed only if stakeholders were fully aware of the mutuality of their relationships and the need "to develop a parallel, but distinct programme of education for management concurrently with the projected workers' educational programmes." 3 The link with the University of the West Indies (UWI) helped to broaden the perspective on education and training to be more inclusive and expanded its course offerings to the less privileged across the Caribbean region. The workers who were members of the trade unions in the Caribbean were largely drawn from that "lower class," and therefore there was a need to introduce and develop specialized training courses/programs that would reflect "the social, cultural and economic needs of the region ... through programmes which had not been made available by the formal system." "Thus, several specialized units were formed, including a trade union unit, to create an awareness among the leaders and members of the trade union movement about trade union and industrial relations issues.

Much of the work in fostering capacity building to further intellectual labor in the creation of a new society is owed to Professor Rex Nettleford, a Caribbean intellectual who spent long years at the University of the West Indies building the extramural department and, later, the School of 
Continuing Education. It was in this vein that education was to be seen by the workers as an empowering force and the University's involvement forming an important contribution to pedagogy, where knowledge would "push boundaries beyond individuals" to create confidence among those whom Nettleford termed "the people from below." As is quite often the case in Nettleford's teaching, the centrality of labor, if nothing else, demands a voice at the workplace, and indeed the wider society, in shaping the social and political environment of the times. ${ }^{5}$

While early labor education focused on sensitizing workers to issues of wages and proper working conditions, there was an absence of a theoretical and institutional analysis that examined these concepts in a holistic manner. The shift in that area began in the early years of the 1960s, primarily through the efforts of Nettleford, Professor George Eaton, and Hector Wynter from the University of the West Indies through regular training programs beginning with the extramural department of the University of the West Indies. ${ }^{6}$ This replaced the ad hoc training programs normally sponsored by the British and US labor movements, with more structured training programs offered by the University of the West Indies, along with the three permanent labor education institutions established in the 1960s. Primarily through the extramural department, trade union education took on a "scholastic determination" throughout the region providing a "broader social context which allowed for a deeper understanding of the interrelatedness of the economic, the social and the political and how they combined to affect the worker's life and living."7

Eaton argued that trade union education and training in the 1970s needed "a new analytical framework or model which could facilitate the integration of multidisciplinary studies of the various aspects of trade unionism,"8 an observation furthered in the work of Baker and Wallerstein, who saw labor education as a specialized branch of adult education that attempted to meet the educational needs and interests arising out of workers' participation in the union movement. ${ }^{9}$

This led to a more comprehensive approach to collective bargaining negotiations and the evolution of contract administration developed as Caribbean countries began to redefine the economic and political arrangements in their respective territories in the post-Independence era. Issues of trade liberalization and Caribbean integration meant that the business of industrial relations in Jamaica, Barbados, and Trinidad and Tobago had to be analyzed to determine their effects on the terms and conditions of employment and the conditions of their work. Sectoral diversification and foreign-based investment introduced unprecedented issues for workers in the Caribbean region, as well as the introduction of novel employment practices and production regimes (free zones, etc.), which meant that beyond understanding the dynamics of an emerging global arrangement and trade, workers and workers' organizations had to develop appropriate responses to safeguarding the interest of the working-class. In recognition of these challenges, the core mission of the labor colleges was to develop the representational capacity of unions by improving the competency of union officials in various labor-related disciplines/areas with an emphasis 
on the socioeconomic context influencing trade union praxis, labor-management relations, and trade union management. Over time, the colleges extended their course offerings to employers and the general public in an attempt to heighten awareness and promote solidarity among the social partners.

Our focus will be on three labor colleges that exist in the English-speaking Caribbean. The oldest is the Hugh Lawson Shearer Trade Union Education Institute (previously known as the Trade Union Education Institute) founded in Jamaica in 1963. The Cipriani Labour College was later established in Trinidad and Tobago in 1966, and the Barbados Workers' Union Labour College was established in 1974 as an arm of the Barbados Workers' Union. All three labor colleges are partly funded by national governments and trade unions. Various NGOs from the regional and international community had also provided financial support for various programs developed by the labor colleges.

Labor colleges in Barbados, Jamaica, and Trinidad and Tobago have had a strong/close affiliation with the founding unions within their respective territory. The Barbados Workers' Union Labour College is an arm of the Barbados Workers' Union. The founding unions of the Hugh Lawson Shearer Trade Union Education Institute (formerly the TUEI), were the National Workers' Union (NWU), the Bustamante Industrial Trade Union (BITU), and the Trade Union Congress (TUC); while in Trinidad, the Cipriani College of Labour and Cooperative Studies was named after Captain A. A. Cipriani, a labor leader and president of the Trinidad Workingmen's Association.

\section{The Hugh Lawson Shearer Trade Union Education Institute (HLSTUEI)}

Background The Trade Union Education Institute was established in 1963 on the University of the West Indies, Mona campus, as a unit in the extramural department. The Institute was a gift from the government of the United States, through the United States Agency for International Development (USAID), as part of the cooperative program in education. Its establishment was supported by the government of Jamaica and the University of the West Indies. The Institute's founding unions were the Bustamante Industrial Trade Union, the National Workers' Union, and the Trades Union Congress of Jamaica. The key aims of the Institute are to provide training courses, lectures, and classes in labor education; to foster the development of healthy industrial relations, and to promote research into industrial relations and labor studies' issues in Jamaica and the region.

Currently the Institute is one of the four units in the Consortium for Social Development and Research within the UWI Open Campus. The other three units within the Consortium are the Caribbean Child Development Centre (CCDC), Social Welfare Training Centre (SWTC), and the Women and Development Centre (WAND). The HLSTUEI is the specialist unit within the Consortium that focuses specifically on labor education, outreach, and 
labor market research. Much of the research conducted seeks to address the multifaceted impact of globalization on Caribbean workers.

Workshops and Short Courses To meet the constant demands of workers in a dynamic labor environment, the Institute has hosted numerous workshops and symposia across the Caribbean region autonomously or jointly with the social partners. During the last ten years the Institute has collaborated with various government organizations and NGOs that have committed their efforts to improving the livelihood of workers across the region. A few of these organizations are the ILO, Friedrich Ebert Stiftung (FES), the Jamaica Confederation of Trade Unions (JCTU), and the Ministry of Labour and Social Security (MLSS).

In recent times the Institute introduced a certificate course in productivity management and expanded its work in the rural areas of Jamaica with the hosting of several workshops on topical issues such as climate change, sexual harassment, occupational safety and health and grievance handling with the support of the UWI Open Campus sites across the island. The Institute also hosts a series of short courses during each academic year leading to a certificate in labor studies, which matriculates successful students into a full degree programme. During the 2009-2010 academic year, the Institute began hosting two short courses on computer training and professional conduct in the workplace. Both courses were strategically designed to give participants a competitive edge within the contemporary labor market by improving their ethical knowledge and technical skills. The Professional Conduct and Protocols for the Workplace course was established in response to a desire expressed by employers for an improvement in the work ethics and professionalism within the general labor force. The computer course was developed based on a request by union leaders and management to improve the computer skills of delegates and trade union officers. This concern arose because of the technological changes occurring within the workplace associated with the process of globalization. The course introduced participants to fundamental computer training that would improve their competency and performance.

\section{The Barbados Workers' Union Labor College}

Background The Barbados Workers' Union Labour College was established as a residential educational arm of the Barbados Workers' Union. The college was created to meet the educational needs of BWU members, especially within the context of leadership and management. The establishment of the College is credited to the efforts of Sir Frank Walcott, Evelyn Greaves, Lawrence Nurse, and Le Roy Trotman. Sir Frank Walcott and Evelyn Greaves were elected to the House of Assembly in first elections held in an independent Barbados.

The American Institute for Free Labour Development (AIFLD) provided a loan of $\$ 50,000$ interest free to the Barbados Workers Union (BWU) for the building of the college. In 1974 the college was officially opened at Mangrove, 
St. Phillip. Among the officials who visited were Errol Barrow (Prime Minister), Erskine Sandiford (Minister of Education), and Bill Doherty (AIFLD representative). During that period several other officials visited, including the then President of Zambia, Dr. Kenneth Kaunda. The first advisory board for the college comprised Frank Walcott (Chairman), Claude Skeete, Le Roy Trotman, Keith Seale, Dr. Keith Hunte, Dr. Leonard Shorey, Rev. Sehon Goodridge, Senator Maurice King, C. Husbands, and Evelyn Greaves (principal).

In 1976, the college underwent further developments with the construction of a residential complex within the vicinity of the college. The addition made BWULC the only labor college in the Caribbean with residential facilities for students and staff. The residential complex has also provided a source for generating additional revenue for the institution. Currently the complex has twenty dormitory rooms that provide accommodation for thirty-six students on a double-occupancy basis.

Course Offerings Diverse employment practices within regional and international spheres have prompted the college to develop a series of short courses and training workshops to meet the demands of stakeholders. Programs are designed to appeal not only to trade union membership, but also a wider crosssection of persons who are interested in industrial relations matters. Some topical areas covered by these training courses cover areas related to negotiations and collective bargaining, occupational safety and health, financial planning, communications, and human resource management. Courses are also offered in economics, sociology, and politics.

The college offerings were extended to include a Certificate in Industrial Relations (CIR). The course focuses on critical industrial relations themes related to conflict resolution, occupational safety and health, grievance handling, gender issues, worker rights, and information technology. Upon successful completion of the course participants are awarded a national vocational qualification. The CIR is among the few certificate programs developed by a regional labor college that is offered online.

The primary mode of delivery for short courses is face-to-face interaction. Lectures and small-group discussions are key features of the delivery process. The CIR, however, has an online component that seeks to extend the reach of the college. This online capacity facilitates greater access and dissemination of information in a flexible manner. Registration for both the CIR and computer school programs can be completed online.

\section{Cipriani Labor College}

Background Labor education in Trinidad and Tobago emerged in the 1950s as a result of growing interest of the Ministry of Labor to improve the skills and competencies of trade union officials. Initial efforts to formalize labor education training began with a series of short courses in trade unionism, industrial 
relations, civics, and economics. The courses offered basic training to trade unionists and over time extended to management personnel. The increased demand for labor education training led to high-level discussions between government and trade union officials to improve the quality of labor education in the country.

The government eventually decided to establish a labor college to provide specialized training in the form of workshops, seminars, and other activities within the context of industrial relations. The ILO agreed to provide technical support by providing an expert to assist with the establishment and directorship of the college. In August 1966, Mr. Max Swerdlo of the Canadian Labor Congress was appointed director of the College. The legal framework outlining the structure and function is enshrined in the Cipriani Labor College Act of 1972. The Act distinguished Cipriani Labor College from other labor colleges in the Caribbean by establishing a separate board of governors independently selected by the minister to manage its operations.

Course Offerings and Delivery The college began in 1975 by offering a series of short courses and a two-year diploma in cooperative studies. The diploma program contributed significantly to improving the professionalism of management and trade union personnel. The program was also essential in shaping the administrative policy and management structure of cooperative entities throughout the country. The CLC is the only labor college in the Caribbean that offers special training in cooperative studies. This feature makes the CLC unique within its category because it has a dual obligation to both the labor movement and the cooperative movement within the country.

Over the next two decades the college would expand its course offerings to attract a wider target audience. With the support of the ILO and the National Safety Council, a one-year part-time program in occupational safety and health was introduced. Short courses in security administration and management, public relations, human resource management, marketing, and administrative office management were offered to members of the general public. In 1995 a diploma in human resource management was developed along with a certificate in environmental management. In December of that same year CLC became the first labor college to deliver a computer training diploma by establishing a computer training laboratory. A special course in project planning and implementation was later introduced in 1997.

To improve the academic stature of the college, an associate degree program was developed in 1998. Associate degrees were offered in security administration and management, occupational safety and health, project management, and environmental management. Between 2001 and 2010 the college widened its course offerings by launching bachelor degree programs. Within this time frame CLC began to offer bachelor degrees in labor studies and occupational safety, health and environment, human resource management, and project management. Regarding cooperative programs, two bachelor programs were established in 2009. 
Contribution of Labor Colleges to the Caribbean It is quite clear that labor colleges have played a vital role in empowering the labor movement across the Caribbean. However, given the increasing economic globalization and restructuring of Caribbean economies and the need for greater knowledge of the system, the need for a different approach to workers' education has become obvious. This is because in facing the effects of unfair globalization, attacks on their existence by supporters of neoliberalism, and rapidly changing technology in the workplace, unions recognized that the key to effectively understanding and addressing these issues is labor education. ${ }^{10}$

Many unions in the region have seen the effects of globalization as an assault on the working class and an attempt at deunionization of the workforce. The most likely response would be to "fight back," to see the ideal type of trade union as one in which industrial relations must now be reduced to "schools of war in a struggle between labour and capital."11 Where trade unions perceive their role as one of conflict, this would undoubtedly affect the emphasis they would place on their own workers' education program. By contrast, labor colleges have been able to move away from the narrow understanding of trade unionism and industrial relations, rooted as they are in this notion of adversarialism, and to adopt a more solution-oriented approach to labor education. They have also been able to improve the funding of union education, linking it to labor research and workplace issues. They have made it relevant to a broader spectrum of working people, updating its methodologies and training its practitioners to help the movement learn how to create the new knowledge it needs to face the challenges ahead.

As the emerging dynamics of the twenty-first-century labor market unfolds, labor colleges in the Caribbean, of necessity, have had to reexamine their structures, functions, curricula, and approaches in order to protect the rights and interests of the workforce and to create a climate for greater efficiency. While the potential for greater levels of competitiveness is said to exist under a much more open and expansive global economy, the emerging trends in the field of industrial relations have shown signs of precarious employment practices through part-time work, fixed-term contracts, and the reduction of such benefits as health insurance and pension schemes. The challenge to the regional labor colleges therefore was whether labor education was going to be "transformatory" or "accommodatory." 12 Indeed, labor colleges have responded to this new wave of globalization with short courses, workshops, and seminars that enhance participants' understanding of the impact of global forces on labor market trends in the Caribbean.

In the last three decades, the worker education agenda in the Caribbean has focused primarily on issues relating to the improvement of wages and conditions of work and job security for workers. The labor colleges have responded appropriately by developing various short courses and/or programs that seek to address these growing concerns. The pedagogical focus of the labor colleges is centred on designing programs that provide pertinent solutions for issues affecting workers in a manner that is not overly technical or convoluted. Typically, 
support for curriculum development is sometimes solicited from experts or academics from various disciplines. HLSTUEI has worked with academics from Brown University and the University of Illinois, Urbana-Champaign, within areas related to models of collective bargaining, while the BWU labor college has often sought technical assistance from the ILO.

It was envisioned in those formative years that strong trade unions, supported by an educated workforce would contribute to the social and economic development of Caribbean territories, and that labor education was directed toward leading that social change. But with the decline in trade union membership, and the very survival of trade unions across the Caribbean becoming a matter of concern, labor colleges now must play an active role in ensuring that workers are educated to the significance of organized labor as an important labor market institution and a key partner in development contribution to the growth of markets and democratic institutions. For sure, labor colleges have helped to identify the unavoidable, immediate challenges associated with globalization but must quickly develop programs that offer alternatives to current trends that counter the sense of "inevitability" driving the globalization ideology and locate organized labor as part of that countervailing force to influence the course and content of the region's economic progress. ${ }^{13}$

Caribbean Leadership The various founders and directors of the labor colleges have also made laudable contributions to the Caribbean, especially in relation to academics, politics, and trade union development. Among this group are a few individuals who have been internationally recognized as stalwarts within their respective areas of specialization. From the BWULC the work of Frank Walcott and LeRoy Trotman are deeply respected and admired regionally and internationally. Frank Walcott served as president of the Caribbean Congress of Labor for three consecutive terms, was an active member of the ILO governing body, and served on the executive board of the International Confederation of Free Trade Unions (ICFTU). He was also a member of the American Institute for Free Labor Development and a former Chairman of the World Employment Conference. His compatriot LeRoy Trotman was renowned regionally for his contributions to the labor movement. He is also a former president of the ICFTU.

For HSLTUEI, one of its founding fathers, Michael Manley, is revered for his contribution to politics, trade union development (regionally), and Caribbean integration. Michael Manley is considered to be one of the most popular Prime Ministers in the Caribbean within the post-Independence period. He was a strong advocate of policies and legislation geared toward empowering the working class. Rex Nettleford, George Eaton, Hector Wynter, and Hugh Lawson Shearer would count among other academics and trade union leaders whose influence in advancing workers' education through the labor college would have added to a stream of Caribbean intellectual tradition where labor leaders have undoubtedly made significant contribution to the process of national development. 


\section{Conclusion}

Labor education is of crucial importance to the development of labor movements across the Caribbean. The work of the three labor colleges examined served as a major cornerstone in preparing the movement for the adversities associated with the globalization process by providing training and academic support to trade unions. Over time, the colleges transformed their pedagogic processes by adopting contemporary modalities of delivery to expand program offerings and enhance their appeal to the wider employed labor force. A common strategy is the delivery of programs online. While the reputation of the colleges has grown, they are still experiencing significant challenges, especially of collaboration and funding.

What has long been established through labor education in the Caribbean is the relationship between learning and society. In regard to the challenges the regional labor movements face in terms of their own survival, labor education must broaden its outreach to meet the underserved communities of the region and further deepen the scope of its work to address the wider economic, social, and political environment in which social relations contend. ${ }^{14}$ If regional societies are to meet the expectations and desires of their citizens in the context of a redefinition of a development paradigm, labor colleges must adopt a pedagogical approach that facilitates developmental learning.

\section{NOTES}

1. Zin Henry, "Labor Relations in the Caribbean Region" in Labor Relations in Caribbean Countries: Proceedings of a Tripartite Caribbean Seminar on Labor Relations, Castries, St. Lucia, 1-4 November 1988, ed. Werner Blenk. (Geneva, 1994), 5.

2. Patricia Ellis, Angela Ramsay, and Samuel Small, Adult Education in the Caribbean at the Turn of the Century. (Kingston, 2000), 36.

3. Department of Extra Mural Studies, Resolution from the Labour Education Conference, August 17, 1959.

4. Howard Fergus, Lennox Bernard, and Judith Soares, Breaking Down the Walls: An Evolution of the Extramural Department (Kingston, 2007), 103.

5. Anthony Bogues, "Rex Nettleford: The Cane Piece, Labour, Education and the Caribbean Intellectual," Caribbean Quarterly 57 (2011): 20-32.

6. Henry, "Labor Relations in the Caribbean Region," 4-19.

7. Fergus et al., 119.

8. George Eaton, "The Trade Union Education Institute and Rex Nettleford's Philosophical Orientation," Caribbean Quarterly 57 (2011): 5.

9. Robin Baker and Nina Wallerstein, eds., Worker Education and Training in Steven Hecker Encyclopedia of Occupational Health and Safety (Geneva, 2011).

10. International Labor Organization (ILO), The Role of Trade Unions in Workers' Education: The Key to Trade Union Capacity Building. (Geneva, 2007).

11. Richard Hyman, Understanding European Trade Unionism: Between Markets, Class and Society (London, 2001), 2.

12. Ben Salt, "Workers' Education and Neoliberal Globalisation: An Adequate Response to Transnational Corporation?" Adult Education Quarterly 6 (2000): 9-31.

13. Nicholas Burbules and Carlos Torres, eds., Globalisation and Education: Critical Perspectives (London, 2000).

14. Jeffrey Taylor, "Union Learning: Canadian Labor Education in the Twentieth Century," Labor/Le Travail, 49, (2002). 